\title{
Ornithine Transcarbamylase Deficiency: Enzyme Studies on a Further Case and a Method of Diagnosis Using Plasma Enzyme Ratios
}

\author{
R. G. F. GRAY, J. A. BLACK, V. H. LYONS, AND R. J. POLLITT ${ }^{(38)}$ \\ Sheffield Children's Hospital and M.R.C. Unit for Metabolic Studies in Psychiatry, University Department of \\ Psychiatry, Sheffield, England
}

\section{Extract}

The activities of the urea cycle enzymes in the liver of a female patient with hyperammonemia were determined (Table 1). Ornithine transcarbamylase (OTC, EC. 2.1.3.3) was reduced to 5-10\% of normal and the residual enzyme showed an apparent $K_{m}$ orn of 0.69 (normal $0.37 \pm 0.10$ ) $\mathrm{mmol}$ liter. The $\mathrm{pH}$ dependence was normal. The patient's mother also showed hyperammonemia but was not clinically affected.

Consideration of the genetics of the disease suggested that many female patients should have a mixture of normal and mutant enzymes. Electrophoresis of the patient's liver extract showed an additional band of OTC activity probably due to this mutant enzyme.

The ratio of plasma glutamate-pyruvate transaminase to OTC was abnormal in four clinically affected patients with OTC deficiency (Fig. 4B) but not in two of their mothers without clinical signs.

\section{Speculation}

The enzyme ratio method may provide a useful alternative to liver biopsy for diagnosing OTC deficiency. Simple kinetic analysis appears to be inadequate for characterizing the residual liver OTC in female patients and chromatographic or electrophoretic methods should also be used where possible.

Hyperammonemia due to ornithine transcarbamylase (OTC) deficiency is a relatively common inborn error of metabolism. Some 23 affected families were reviewed by Palmer and coworkers (26) and a number of others have been reported. The condition appears to be very variable, both in clinical severity and biochemical findings. The liver OTC levels in patients range from $0.1 \%$ to $25 \%$ of normal, measured at $\mathrm{pH} 7$, while a number of different enzyme variants are recorded. Several features of the disease are puzzling and a clearer picture will probably emerge only from more detailed biochemical study and an examination of the structure and regulation of the enzyme itself.

We have for the past few years been studying a hitherto unreported family with hyperammonemia in both the mother and a female child. The death of this child enabled the detailed enzyme studies reported here to be performed on the residual hepatic OTC. In addition, a new method of diagnosis based on plasma enzyme ratios has been explored. This may enable a strong presumptive diagnosis of OTC deficiency to be made without liver or intestinal biopsy.

\section{PATIENTS}

The family studied (Fig. 1) originated in West Pakistan. The propositus (patient $A$ ) was delivered prematurely at 34 weeks of gestation. On the 6th day she became floppy and unresponsive and rapidly became semicomatose, with short apnoeic episodes. An attempt to obtain a blood ammonia estimation was unsuccessful. During the next 2 weeks she alternated between apparently normal activity when given intravenous fluids (electrolyte and glucose solutions) and semiconsciousness when milk feeds were restarted. On the 21 st day of life the blood ammonia was estimated and found to be $210 \mu \mathrm{mol} /$ liter. She was started on a low protein diet ( $1.4 \mathrm{~g}$ protein $/ \mathrm{kg}$ daily) and a further blood ammonia level on this diet was $57 \mu \mathrm{mol} /$ liter (upper limit of normal). The plasma lysine level was slightly raised (up to $530 \mu \mathrm{mol} / \mathrm{liter}$ ) in several specimens taken in the first few months of life but by 1 year this had returned to normal. Despite some initially good progress, the patient showed evidence of definite psychomotor retardation. While at home, increased episodes of vomiting occurred, associated with high blood ammonia levels. which were almost certainly due to nonadherence to a strict diet. Her condition gradually deteriorated and she died at 3.9 years. With parental consent a limited postmortem examination was performed to obtain the liver and a small section of kidney for biochemical examination. These samples were stored in liquid nitrogen until examined.

The patient's sister is deaf and mentally retarded. There has never been any clinical indication of hyperammonemia and normal blood ammonia values have been recorded on several occasions. Two premature male twins died at 2 days of undetermined causes. Permission was not granted for postmortem examination.

The mother and father both appear physically and mentally normal, although the mother had raised blood ammonia levels (up to $170 \mu \mathrm{mol} /$ liter) both after a small protein load (35) and also in random samples. $n$

Heparinized plasma samples were obtained from three other patients suffering from proven OTC deficiency. These were from the patient $(B)$ of Dr. B. D. Bower (19), the patient $(C)$ of Farriaux et al. (14), and the patient $(D)$ of Dr. M. M. Liberman mentioned in the review by Palmer et al. (26). Plasma samples were also obtained from other children aged 3 months to 15 years undergoing venipuncture for other reasons. Some of these were well at the time whereas others were suffering from a variety of conditions including mild hepatitis. Plasma from a patient $(E)$ with hyperammonemia without OTC deficiency (15) was also examined.

\section{LABORATORY METHODS}

Glutamate oxaloacetate transaminase (GOT) (18), glutamate pyruvate transaminase (GPT) (34), and isocitrate dehydrogenase (ICD) (33) were assayed by standard methods scaled down where appropriate. In the GOT assay the final incubation mixture $(1 \mathrm{ml})$ contained $0.05 \mathrm{ml}$ plasma, $90 \mu \mathrm{mol}$ potassium phosphate (buffered at $\mathrm{pH} 7.4), 30 \mu \mathrm{mol}$ L-aspartate, $10 \mu \mathrm{mol} \alpha$-ketoglutarate, 0.12 $\mu \mathrm{mol} \beta$-NADH, and $0.25 \mathrm{IU}(\mathrm{mM})$ malate dehydrogenase. For the 

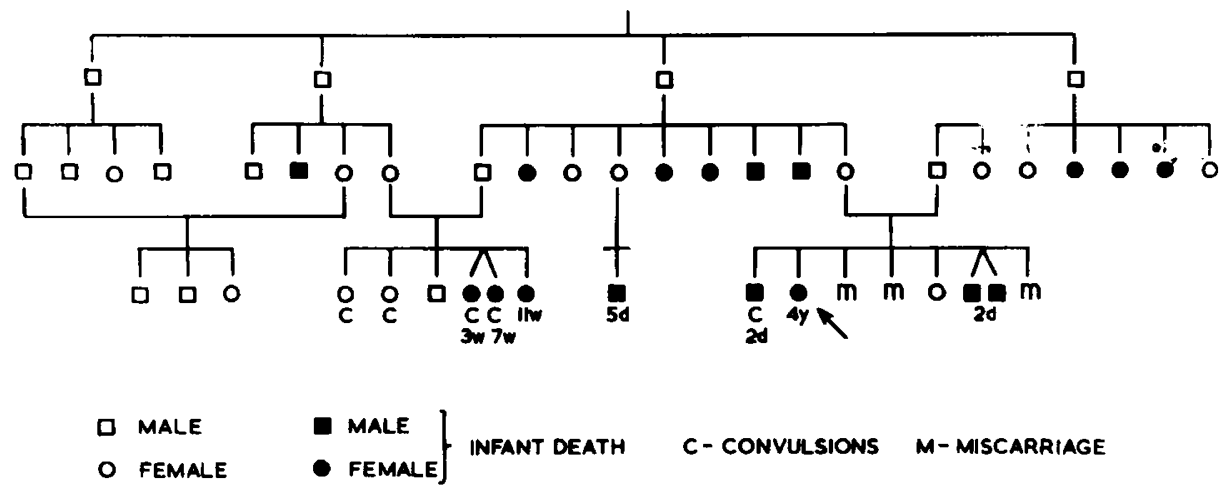

Fig. 1. Family of patient $A$. The arrow indicates patient $A$.

Table 1. Urea cycle enzymes in liver of patient $A$

\begin{tabular}{|c|c|c|c|}
\hline \multirow[b]{2}{*}{ Enzyme } & \multirow{2}{*}{$\begin{array}{l}\text { Activity, } \\
\mu \mathrm{mol} / \mathrm{g} \text { wet } \\
\text { tissue } / \mathrm{hr}\end{array}$} & \multicolumn{2}{|c|}{$\begin{array}{c}\% \text { of control } \\
\text { values }\end{array}$} \\
\hline & & Ref. 9 & Ref. 20 \\
\hline Carbamyl phosphate synthetase & 69 & 51 & 22 \\
\hline Ornithine transcarbamylase, $\mathrm{pH} 7.0$ & 260 & $9.6^{1}$ & 5.0 \\
\hline Argininosuccinate synthetase & 16 & & 44 \\
\hline Argininosuccinate lyase & 66 & 39 & 37 \\
\hline Arginase & 6,700 & 65 & 17 \\
\hline "Lysine dehydrogenase"2 & 52 & & 61 \\
\hline
\end{tabular}

${ }^{1}$ Measured at $\mathrm{pH} 7.7$.

${ }^{2}$ Method of Burgi et al. (4).

GPT assay the incubation mixture $(1.0 \mathrm{ml})$ contained 0.05$) \mathrm{ml}$ plasma $92 \mu$ mol potassium phosphate $(\mathrm{pH} 7.4$ ), $30 \mu$ mol L-alanine, $10 \mu \mathrm{mol} \alpha$-ketoglutarate, $0.12 \mu \mathrm{mol} \beta$-NADH, and 0.128 IU lactate dehydrogenase. In each case incubations were at $35^{\circ}$ and the results corrected to $25^{\circ}$ by multiplying by 0.555 and 0.51 , respectively. For isocitrate dehydrogenase the final incubation mixture $(1 \mathrm{ml})$ contained $0.1 \mathrm{ml}$ plasma and $54 \mu \mathrm{mol}$ Tris- $\mathrm{HCl}$ (pH 7.5), $103 \mu \mathrm{mol}$ sodium chloride, $1.8 \mu \mathrm{mol}$ manganous chloride, $0.15 \mu \mathrm{mol}$ NADP, and $3 \mu \mathrm{mol} \mathrm{D}, \mathrm{L}$-isocitrate. The incubation was performed at $35^{\circ}$ and the result corrected to $25^{\circ}$ by multiplying by 0.445 .

Urea cycle enzymes in liver (Table 1) were determined by the methods of Brown and Cohen (3). Plasma OTC (28) was determined using L-[carbamyl- $\left.{ }^{14} \mathrm{C}\right]$ citrulline and the arsenolysis reaction. The $\left[{ }^{14} \mathrm{C}\right]$ citrulline $(36)$ was , rixed with unlabeled citrulline, recrystallized from aqueous ethanol, and further diluted to give a specific activity of $0.03 \mathrm{Ci} / \mathrm{mol}$. The incubation mixture $(1 \mathrm{ml})$ contained $25 \mu \mathrm{mol} \mathrm{L}$-citrulline and $250 \mu \mathrm{mol}$ arsenate buffered at $\mathrm{pH}$ 7.1. Each determination was carried out in duplicate using $0.5 \mathrm{ml}$ plasma and the incubations were continued for $24 \mathrm{hr}$ at $37^{\circ}$. The blank incubation contained water instead of plasma, duplicate blanks being performed with each set of determinations. The trapping agent for the ${ }^{14} \mathrm{CO}_{2}$ was 2 -methoxyethanol ethanolamine (8:1 by volume) on paper. The papers were counted to 10,000 counts in a toluene-based scintillant.

The apparent Michaelis constants of the liver OTC were measured using mitochondrial lysates (30). The incubation mixture comprised $0.3 \mathrm{ml}$ of $0.4 \mathrm{M}$ triethanolamine- $\mathrm{HCl}$ buffer, $\mathrm{pH}$ 7.5 , and containing the appropriate amount of ornithine hydrochloride, $0.2 \mathrm{ml}$ mitochondrial lysate (30), and $0.1 \mathrm{ml}$ dilithium carbamyl phosphate solution. Incubation was at $37^{\circ}$ for $10 \mathrm{~min}$. For $K_{m}{ }^{\text {orn }}$ a carbamyl phosphate (cp) concentration of $5 \mathrm{mmol} /$ liter was used; and for $K_{m}{ }^{c p}$ an ornithine (orn) concentration of 4 $\mathrm{mmol} /$ liter was used, in both cases at $\mathrm{pH} 7.5$ (triethanolamine$\mathrm{HCl}$ buffer) and at $37^{\circ}$. The apparent $\mathrm{K}_{\mathrm{m}}$ values were calculated by the direct linear plot method (13). Arrhenius activation energy was determined using distilled water extracts of liver, $4 \mathrm{mmol} /$ liter ornithine, and $5 \mathrm{mmol} /$ liter carbamyl phosphate, at $\mathrm{pH} 7.5$, over the temperature range $20-40^{\circ}$. The $\mathrm{pH}$ dependence of the reaction was determined at constant zwitterionic ornithine concentration of $0.25 \mathrm{mmol} /$ liter and $5 \mathrm{mmol} /$ liter carbamyl phosphate at $37^{\circ}(30)$. Triethanolamine-HCl buffers going from $\mathrm{pH} 6.5$ to pH 9.5 in $0.5-\mathrm{pH}$ unit steps were used. The total ornithine concen-

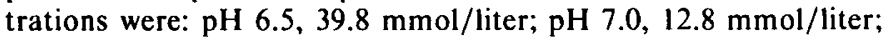
pH 7.5, $4.20 \mathrm{mmol} / \mathrm{liter}$; $\mathrm{pH} 8.0,1.50 \mathrm{mmol} / \mathrm{liter}$; $\mathrm{pH} \mathrm{8.5,0.647}$ $\mathrm{mmol} /$ liter; $\mathrm{pH} 9.0,0.379 \mathrm{mmol} / \mathrm{liter}$; and $\mathrm{pH} 9.5,0.303 \mathrm{mmol} /$ liter. From these results the apparent $\mathrm{pK}$ values of the enzymesubstrate complex were obtained (12). Substrate inhibition by ornithine $(23,30)$ was determined on distilled water extracts using $5 \mathrm{mmol} /$ liter carbamyl phosphate and pH 7.5 (triethanolaminemmol buffer) with ornithine concentrations of 50-500 mmol/liter. Inhibition by orthophosphate was determined on distilled water extracts at an ornithine concentration of $4 \mathrm{mmol} /$ liter and carbamyl phosphate concentration of $5 \mathrm{mmol} / \mathrm{liter}, \mathrm{pH} \mathrm{7.5}$. The apparent $\mathrm{K}_{1}{ }^{\mathrm{PO}} 4$ was determined from a plot of $1 / \mathrm{V}$ against $\left[\mathrm{PO}_{4}\right.$ ]. In all cases incubation times were chosen to limit the consumption of any one substrate to less than $10 \%$. The control livers were necropsy specimens from adults.

Polyacrylamide gel electrophoresis was carried out as described by Marshall and Cohen (22). A portion of liver was homogenized in $0.9 \%(\mathrm{w} / \mathrm{v})$ sodium chloride ( $1 \mathrm{~g}$ liver to $4 \mathrm{ml}$ saline) and the homogenate was centrifuged at $13,000 \times g$ for $20 \mathrm{~min}$ at $4^{\circ}$. The supernatant $(50 \mu \mathrm{l} / \mathrm{tube})$ was used for disc electrophoresis using a 6\% gel with a continuous Tris-borate-EDTA buffer, $\mathrm{pH}$ 8.6. Electrophoresis was at $4^{\circ}$ for $5 \mathrm{hr}$. The gel was then cut into slices and OTC activity was determined by the Reichard method.

Plasma ammonia was determined by resin absorption followed by the Berthelot phenol hypochlorite reaction (Hyland blood ammonia test kit). Protein was determined by the Lowry method.

\section{RESULTS}

\section{UREA CYCLE ENZYMES}

The activities of the urea cycle enzymes from the liver of patient $A$ are shown in Table 1 . All of the values are low compared with those obtained by Levin and coworkers for children's liver by biopsy (20). The values quoted by Cathelineau and coworkers (9) approximate more closely those in our patient. Probably the moribund condition of the patient before death and the pathologic changes in the liver contributed to the low enzyme levels generally. The most severely affected enzyme is ornithine transcarbamylase, the carbamyl phosphate synthetase being only slightly reduced compared with argininosuccinate synthetase and argininosuccinate lyase. The "lysine dehydrogenase" activity was virtually normal. The hyperlysinemia seen in this patient must therefore be considered a secondary feature (7).

Ornithine transcarbamylase activity was also measured in homogenates of kidney cortex and liver by the Reichard (28) 
arsenolysis method. The kidney from patient $\boldsymbol{A}$ gave activities of 0.36 and $0.49 \mu \mathrm{mol} / \mathrm{hr} / \mathrm{g}$ protein compared with $0.58( \pm 0.63)$ $\mu \mathrm{mol} / \mathrm{hr} / \mathrm{g}$ of protein (range $0.05-1.29$ ) in five controls. The variability of these results may reflect the heterogeneity of kidney tissue. Comparable results for liver were: patient $83 \mu \mathrm{mol} / \mathrm{hr} / \mathrm{g}$ protein; control subjects (4) $918( \pm 319) \mu \mathrm{mol} / \mathrm{hr} / \mathrm{g}$ protein (range 534-1210). Thus the deficiency of OTC does not seem to have extended to the kidney enzyme, and the deficiency of the enzyme in the liver is confirmed.

\section{KINETIC STUDIES ON OTC}

Some kinetic parameters of the patient's enzyme and normal enzyme are summarized in Table 2 and Figure 2. The normal $\mathrm{K}_{\mathrm{m}}$ values are comparable to those of Snodgrass (30) and other workers, although the degree of ornithine inhibition was lower than that previously observed (30). Polyacrylamide gel electrophoresis (22) gave different patterns in the patient and in the normal subjects (Fig. 3). About a third of the OTC activity in the patient's liver extract remained near the surface of the gel, possibly because of the relatively high protein content of this extract.

\section{PLASMA ENZYME RATIOS}

The ratios of OTC to GOT, to GPT, and to ICD in the patient's plasma and that of control children is presented in Figure 4. The normal range for adults is similar to that in children. Corresponding ratios for cord blood from healthy babies are summarized in Table 3. The range of OTC values obtained both for a small

Table 2. Kinetic data for ornithine transcarbamylase

\begin{tabular}{|c|c|c|c|}
\hline & \multicolumn{2}{|c|}{ Normal subjects } & \multirow[b]{2}{*}{ Patient $A$} \\
\hline & Range & $\begin{array}{c}\text { Mean } \pm \text { SD } \\
\text { (no. of subjects) }\end{array}$ & \\
\hline $\begin{array}{l}\mathrm{K}_{\mathrm{m}}^{\prime} \text { for carbamyl phosphate, } \\
\mathrm{mmol} / \text { liter }\end{array}$ & $0.17-0.33$ & $0.27 \pm 0.06(5)$ & 0.26 \\
\hline $\mathrm{K}_{\mathrm{m}}^{\prime}$ for ornithine, $\mathrm{mmol} / \mathrm{liter}$ & $0.29-0.47$ & $0.37 \pm 0.10(5)$ & 0.69 \\
\hline $\mathrm{K}_{\mathbf{t}}$ for phosphate, mmol/liter & $6.8-12.2$ & $9.7 \pm 2.2(4)$ & $14.4,15.3$ \\
\hline $\mathrm{K}_{\mathrm{i}}$ for ornithine, $\mathrm{mmol} / \mathrm{liter}$ & $580-1030$ & $861 \pm 197(4)$ & $1,120,1,730$ \\
\hline $\begin{array}{l}\text { Apparent activation energy, } \\
\text { Kcal }\end{array}$ & $12.2-15.4$ & $14.4 \pm 1.2(5)$ & $13.2 \pm 0.7(3)$ \\
\hline $\begin{array}{l}\text { Denaturation rate constant, } \\
\sec ^{-1}\end{array}$ & & $3.95 \times 10^{-6}(1)$ & $4.75 \times 10^{-6}$ \\
\hline \multirow[t]{2}{*}{ pK values } & $7.24-7.52$ & $7.34 \pm 0.16(3)$ & $7.36,7.39$ \\
\hline & $8.33-8.43$ & $8.39 \pm 0.05(3)$ & $8.42,8.50$ \\
\hline $\begin{array}{l}\text { Ratio, forward to reverse } \\
\text { (arsenolysis) reaction }\end{array}$ & $20.2-26.3$ & $23.2 \pm 2.5(4)$ & 29.5 \\
\hline
\end{tabular}

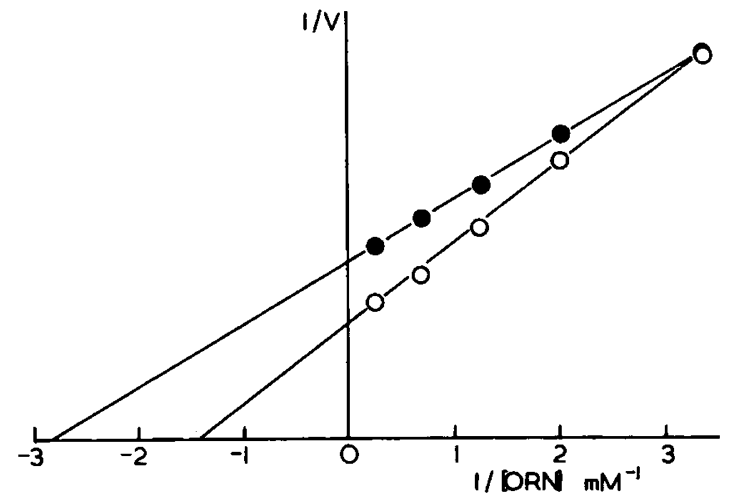

Fig. 2. Lineweaver-Burk plot for hepatic ornithine transcarbamylase. Control sample ; patient $A, O$. Each point is the mean of two determinations. The apparent $\mathrm{K}_{\mathrm{m}}$ orn for the patient is $0.69 \mathrm{mM}$, for the control, $0.35 \mathrm{mM}$. ORN: ornithine.

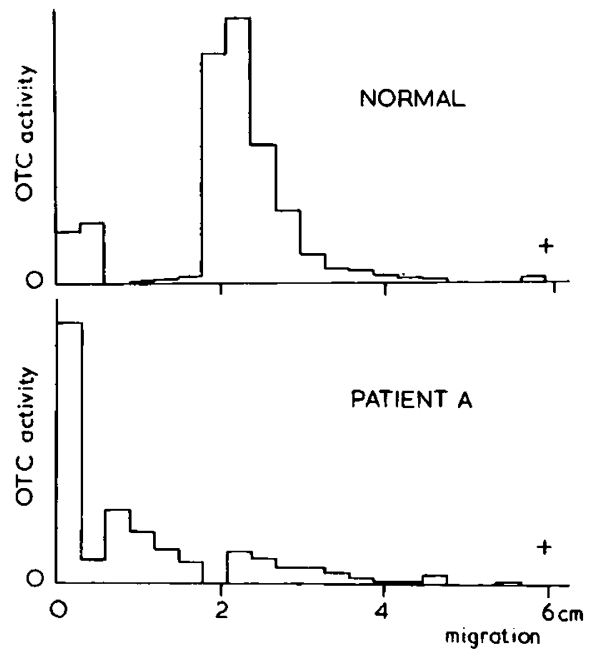

Fig. 3. Polyacrylamide gel electrophoresis. The supernatant solution from liver homogenized in $0.9 \% \mathrm{NaCl}$ was subjected to electrophoresis in $6 \%$ polyacrylamide gel, $\mathrm{pH} 8.3$, at $4^{\circ}$. After electrophoresis gels were sliced into 3-mm sections and assayed by the Reichard method. OTC: ornithine transcarbamylase.

sample of healthy adults and the children extended lower than that reported by Reichard (28).

\section{DISCUSSION}

\section{MODE OF INHERITANCE}

It is generally agreed $(8,26,29)$ that OTC deficiency is transmitted as an X-linked condition, the affected males usually dying early. The variable severity of the disease in the female heterozygotes is attributed to differential lyonization of the $X$ chromosome. Various other possibilities are discussed at length by Cathelineau and coworkers (8). The poor survival record of patient $A$ 's sibs is striking, only one child now surviving from a possible total of seven. A preponderance of abnormal over normal offspring of females carrying the trait has been noted by Palmer and coworkers (26), but in few instances have all the abnormal children been adequately investigated. The poor mental development of the surviving child in our family could be due to the effect of the mother's hyperammonemia in utero, since the child herself did not have hyperammonemia. Indeed, it is possible that patient $A$ was similarly affected by maternal hyperammonemia.

\section{KINETICS OF RESIDUAL OTC}

Significant abnormalities in the kinetic properties of the residual enzyme in several cases of partial OTC deficiency have been reported (Table 4 ). Considerably raised apparent $K_{m}{ }^{\text {orn }}$ has been found in two cases; moderately raised apparent $K_{m}{ }^{\text {cp }}$ has been demonstrated in two other families. Apart from this there is a marked and unexplained tendency for low $K_{m}$ values to be obtained for residual OTC, although in only one case (21) was this definitely considered to be outside the normal range.

The variability of previously reported $\mathrm{K}_{\mathrm{m}}$ values for OTC, even using mitochondrial lysates (30), makes us cautious in assessing the significance of the high apparent $\mathrm{K}_{\mathrm{m}}{ }^{\text {orn }}$ in patient $A$, even though it is clearly outside our own normal range. However, the abnormalities in $K_{i}$ for ornithine and phosphate and in the ratio of forward to reverse reaction, although small, do reinforce the suggestion of a structural abnormality in the residual enzyme. This combination of a normal $\mathrm{pH}$ dependence with raised apparent $\mathrm{K}_{\mathrm{m}}{ }^{\text {orn }}$ in the absence of lowered $\mathrm{K}_{\mathrm{i}}{ }^{\text {orn }}$ has not previously been described. 
NATURE OF RESIDUAL OTC

In females heterozygous for OTC deficiency the paternally derived $\mathrm{X}$ chromosome should code for the normal enzyme and this might be expected to account for the residual activity. However, the residual OTC in females often showed abnormal kinetic properties (Table 4) and in 7 of the 11 cases studied had markedly abnormal pH dependence (compared with 6 of 7 males). This suggests that in these cases not only was lyonization unfavorable to the normal (paternal) $X$ chromosome but also the maternal $X$ chromosome was coded for a structural mutant of OTC with considerable residual activity. The observed activity would then be due to a mixture of normal and mutant enzymes. Such a mixture might be expected to produce a nonlinear Lineweaver-Burk plot, but this was not seen in our own case (Fig. $2)$ nor in three other female cases with abnormal $\mathrm{K}_{m}$ values $(6,24)$. In fact, unless substrate concentrations are varied over a considerable range, the deviation from linearity would be small and within experimental error (11). The observed $\mathrm{K}_{\mathrm{m}}$ would be intermediate between the $K_{m}$ values of the two enzymes. The results described by Cathelineau and colleagues (6) can be interpreted in this way. The mother, with a higher OTC activity and hence a greater proportion of normal enzyme, showed a more nearly normal $\mathrm{K}_{\mathrm{m}}{ }^{\mathrm{cp}}$ (Table 4).

The residual OTC activity has been characterized in one patient
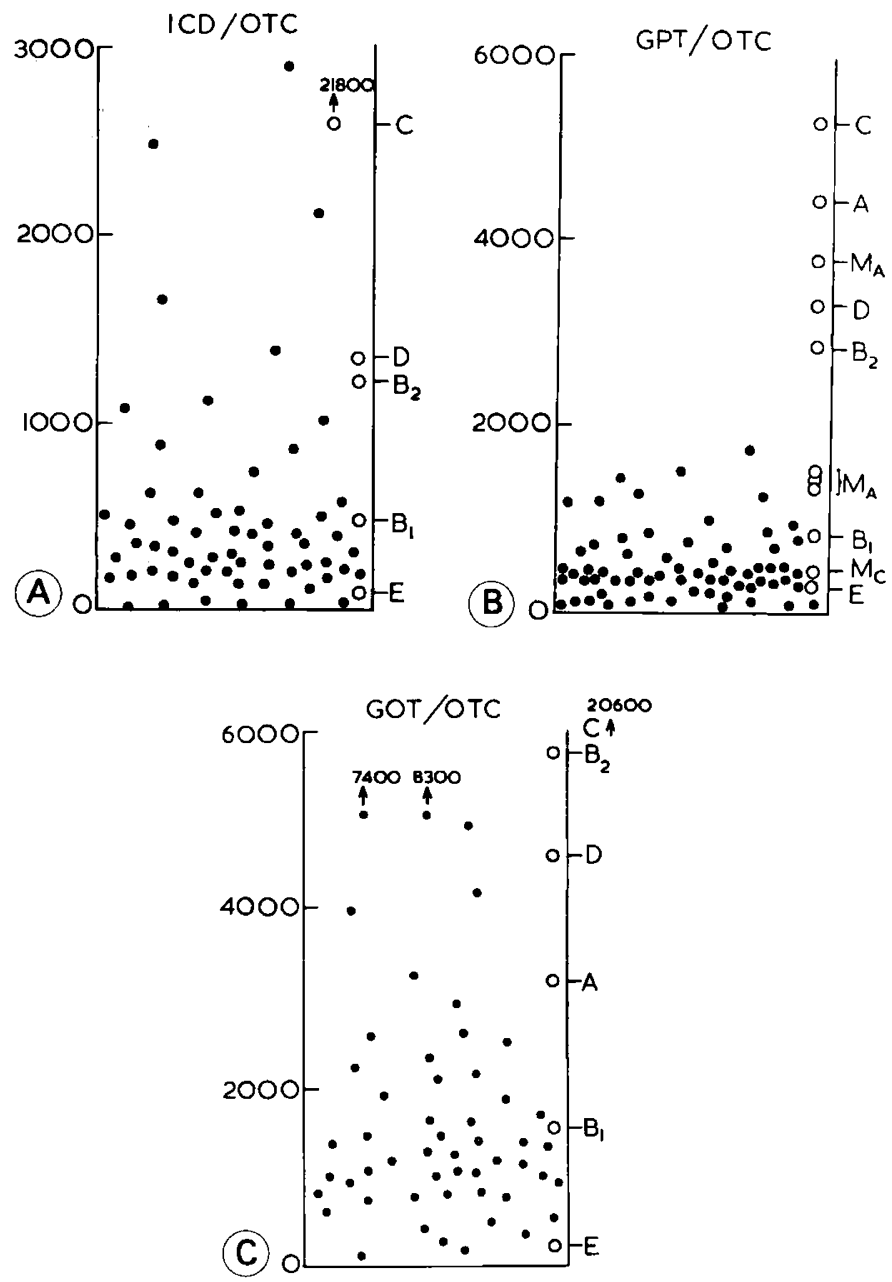

Fig. 4. Plasma enzyme ratios. Solid circles (O) represent samples from control children; open circles (O) are from patients $A-E$ and from the mothers, $M_{A}$ and $M_{C}$ of patients $A$ and $C$, respectively, as indicated on the right of each diagram. The ratios are from results expressed in micromoles liter ${ }^{-1} \mathrm{hr}^{-1}$, at $25^{\circ}$ for glutamate pyruvate transaminase (GPT), glutamate oxaloacetate transaminase (GOT), and isocitrate dehydrogenase (ICD), at $37^{\circ}$ for ornithine transcarbamylase (OTC) (see "Laboratory Methods").
Table 3. Plasma enzyme ratios in cord blood ${ }^{1}$

\begin{tabular}{lrrrc}
\hline \multicolumn{1}{c}{ Ratio $^{2}$} & Range & Mean & SD & $\begin{array}{c}\text { No. of } \\
\text { samples }\end{array}$ \\
\hline GOT/OTC & $11-6,540$ & 1,580 & 1,510 & 18 \\
GPT/OTC & $3-1,930$ & 400 & 284 & 32 \\
ICDH/OTC & $5-3,210$ & 684 & 654 & 15
\end{tabular}

${ }^{1}$ GOT: glutamate oxaloacetate transaminase; OTC: ornithine transcarbamylase; GPT: glutamate pyruvate transaminase; ICDH: isocitrate dehydrogenase.

${ }^{2}$ Ratio is of results expressed in micromoles per liter per hr for both enzymes.

Table 4. Summary of kinetic details for all ornithine transcarbamylase (OTC)-deficient patients

\begin{tabular}{clccc}
\hline Reference & Sex & $\begin{array}{c}\text { Abnormal } \\
\text { dependence }\end{array}$ & $\mathbf{K}_{\text {m }}^{\prime \text { cp 1 }}$ & K $_{\text {m }}^{\text {orn 1 }}$ \\
\hline 5 & M & No & 0.78 & 0.24 \\
6 & F & & 3.9 & 0.55 \\
& $F^{2}$ & Yes & 2.4 & 0.72 \\
8 & M & Yes? & 0.62 & 0.85 \\
9 & M & Yes & 0.52 & 100 \\
21 & M & Yes & 0.28 & 0.71 \\
24 & F & Yes & 4.3 & 0.86 \\
$32^{3}$ & F & & 0.32 & 18 \\
This case & F & No & 0.96 & 1.9 \\
\hline
\end{tabular}

${ }^{1}$ Expressed as ratio to normal values under the same conditions.

${ }^{2}$ Mother of case above.

${ }^{3}$ In patient with Reye's syndrome; low $\mathrm{K}_{1}$ for both substrates (see also Reference 17).

by chromatography on carboxymethyl Sephadex (25) and in another by isoelectric focusing $(1,24)$. In each case two peaks of OTC activity were seen in normal subjects, one of which was missing in the patient. In contrast to this, our low resolution polyacrylamide gel electrophoresis gave only one band of activity from normal liver, but showed two bands from the liver of patient $A$. This appears to support the enzyme mixture hypothesis outlined above. However, a considerably greater knowledge of the normal human enzyme is required before we can interpret this type of result with any confidence.

\section{ENZYME RATIOS}

The definitive diagnosis of OTC deficiency as the cause of a hyperammonemia rests on the determination of the hepatic urea cycle enzymes. Intestinal OTC also seems to be affected in those cases where it has been examined, although sometimes to a lesser extent than the liver enzyme (6). Open liver biopsy has proved fatal in OTC deficiency and although needle biopsy is a practical alternative in many cases, the possibility that the small samples of tissue obtained may not be representative of the whole organ must be considered.

This is especially true in females where lyonization of the chromosome carrying the normal enzyme may be irregular (29). OTC is present in plasma but its absolute amount is of no value in diagnosing OTC deficiency since leakage from the liver, the main site of OTC (27), is very variable. We considered that the ratio of OTC to some other liver enzyme might provide a better indication of hepatic OTC status. Of the commonly estimated liver enzymes, glutamate pyruvate transaminase gave the most discrete normal range of ratios with OTC (Fig. 4). The ratio was not markedly dependent on absolute level of glutamate pyruvate transaminase (Fig. 5). 


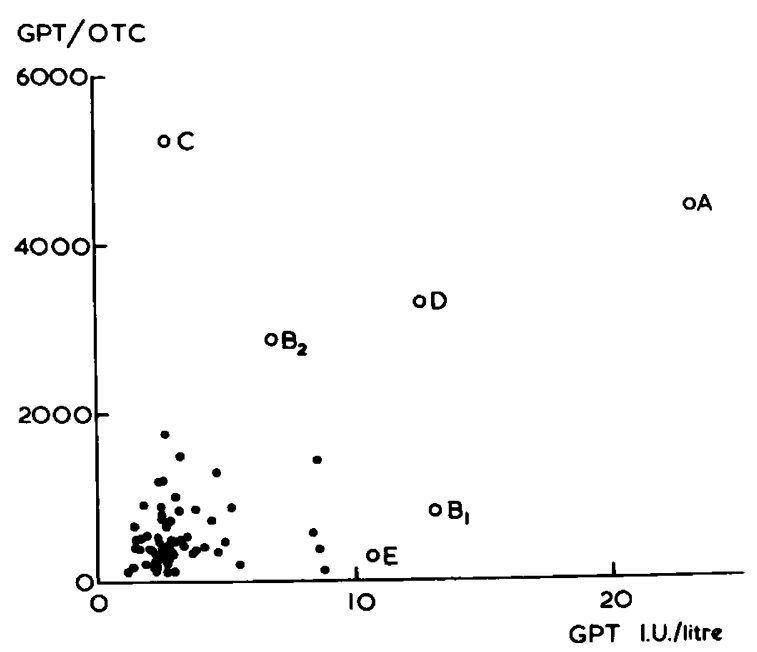

Fig. 5. Variation of glutamate pyruvate transaminase $(G P T)$ /ornithine transcarbamylase $(O T C)$ ratio with GPT level. Details as for Figure 4.

Good discrimination from "normal subjects" was obtained in three of the four clinically affected cases of OTC deficiency examined. In the fourth case the first sample ( $B I$ in Fig. 4) which had taken 2 days to arrive at the laboratory in warm weather gave a ratio within the normal range while the second sample $(B 2)$, which was transported deep frozen, was in the abnormal range.

The ratio method did not distinguish the two mothers examined from normal subjects, although one sample from the mother of patient $A$ gave an abnormal result. Thus it appears that the ratio method will be useful only in subjects with a sufficiently severe defect of OTC to cause clinical illness and it cannot be used for family studies. The normal ratio found in the patient $(E)$ with hyperammonemia but normal OTC activity $(15,16)$ suggests that the hyperammonemia itself is not responsible for the abnormal ratios. The very large range of ratios found in normal cord blood (Table 3) might seem to preclude the use of this as a test material, although the upper limits of the ratios are similar to those seen in older children.

There are possible pitfalls in the interpretation of this test. Both OTC and GPT levels in serum can be influenced by extreme manipulation of diet (2), but the effect is relatively small. Particular care also may be necessary when the serum enzyme levels are fluctuating rapidly since the time course of release and decay of the two enzymes will not necessarily coincide. Indeed, considering that OTC is a mitochondrial enzyme and GPT is mainly in the cytosol, the degree of correlation in the normal subjects is surprising. It should also be borne in mind that where enzymes of abnormal structure are concerned the results from the Reichard method, based on the reverse reaction, may not reflect the activity of the enzyme for the forward reaction. Unfortunately, although the forward reaction is faster, significant nonenzymatic reaction occurs (31), giving high blank values for normal serum OTC levels. These can be reduced by careful design of method (10).

\section{SUMMARY}

The ratio of glutamate pyruvate transaminase to OTC in peripheral plasma may be a useful indicator of hepatic OTC deficiency in cases of severe hyperammonemia. However, the situation is complicated by the very variable biochemical features of OTC deficiency as revealed by enzymatic studies on liver. A majority of cases apparently have mutant OTC with considerable residual activity. Currently available methods of characterizing human OTC variants appear inadequate, particularly in female patients such as the one presented here, in whom a mixture of normal and mutant enzymes is to be expected. Purely kinetic investigations are at present too inaccurate to give much information and need supplementing by the development of chromatographic or electrophoretic methods of characterization.

\section{REFERENCES AND NOTES}

1. Arashima, S., and Matsuda, I.: Ornithine transcarbamylase, an iso-electric point (pI) isozyme in human liver and its deficiency. Biochem. Biophys. Res. Commun., 45: 145 (1971).

2. Brohult, J.: Effects of high protein and low protein diets on ornithine carbamoyl transferase activity in human serum (S-OCT). Acta Med. Scand., 185: 357 (1969).

3. Brown, G. W., and Cohen, P. P.: Comparative biochemistry of urea synthesis. I. Method for the quantitative assay of urea cycle enzymes in liver. J. Biol. Chem., 234: 1769 (1959).

4. Bürgi, W., Richterich, R., and Colombo, J. P.: L-Lysine dehydrogenase deficiency in a patient with congenital lysine intolerance. Nature, 211: 854 (1966).

5. Campbell, A. G. M., Rosenberg, L. E., Snodgrass, P. J., and Nuzum, C. T.: Ornithine transcarbamylase deficiency: A cause of lethal neonatal hyperammonemia in males. N. Engl. J. Med., 288: 1 (1973).

6. Cathelineau, L., Navarro, J., Aymard, P., Baudon, J. J., Mondet, Y., Polonovski, C., and Laplane, R.: Hyperammoniemie hereditaire par anomalie qualitative de l'ornithine-carbamyl-transferase hepatique et intestinale. Arch. Franç. Pediat., 29: 713 (1972).

7. Cathelineau, L., Saudubray, J. M., Charpentier, C., and Polonovski, C.: Letter to the Editor. Pediat. Res., 8: 857 (1974).

8. Cathelineau, L., Saudubray, J. M., Navarro, J., and Polonovski, C.: Transmission par le chromosome $X$ du gene de structure de l'ornithine-carbamyl-transferase: Etude de trois familles. Ann. Genet., 16:-173 (1973).

9. Cathelineau, L., Saudubray, J. M., and Polonovski, C.: Ornithine carbamyl transferase: The effects of $\mathrm{pH}$ on the kinetics of a mutant human enzyme. Clin. Chim. Acta, 4l: 305 (1972).

10. Ceriotti, G.: Optimal conditions for ornithine carbamyl transferase determination: A simple micromethod without deproteinization. Clin. Chim. Acta, 47: 97 (1973).

11. Dixon, M., and Webb, E. C.: Enzymes, Ed. 2, p. 87 (Longmans, Green \& Co., London, 1964).

12. Dixon, M., and Webb, E. C.: Enzymes, Ed. 2, p. 116 (Longmans, Green \& Co., London, 1964).

13. Eisenthal, R., and Cornish-Bowden, A.: The direct linear plot: A new graphical procedure for estimating enzyme kinetic parameters. Biochem. J., 139: 715 (1974).

14. Farriaux J P. Dhondt, J. L. Cathelineau, L., Ratel, J., and Fontaine, G.: Hyperammonemia through deficiency of ornithine carbamyl transferase. $Z$. Kinderheilkd., 118: 231 (1974).

15. Fell, V., Pollitt, R, J. Sampson, G. A., and Wright, T.: Ornithinemia, hyperammonemia and homocitrullinuria: A disease associated with mental retardation and possibly caused by defective mitochondrial transport. Amer. J. Dis. Child., 127: 752 (1974).

16. Gatfield, P. D., Taller, E., Wolfe, D. M., and Haust, M.D.: Hyperornithinemia, hyperammonemia and homocitrullinuria associated with decreased carbamyl phosphate synthetase I activity. Pediat. Res., 9: 488 (1975).

17. Hommes, F. A.: Discussion. In: F. A. Hommes and C. J. Van Den Berg: Inborn Errors of Metabolism, p. 216 (Academic Press, New York, 1973).

18. Karmen, A.: A note on the spectrophotometric assay of glutamic oxalacetic transaminase in human blood serum. J. Clin. Invest., 34: 131 (1955).

19. Krebs, H. A., Hems. R., and Lund, P.: Regulatory mechanisms in the synthesis of urea. In: F. A. Hommes and C. J. Van Den Berg: Inborn Errors of Metabolism, p. 201 (Academic Press, New York, 1973)

20. Levin, B., Abraham, J. M., Oberholzer, V. G., and Burgess, E. A.: Hyperammonaemia: A deficiency of liver ornithine transcarbamylase. Occurrence in mother and child. Arch. Dis. Childhood, 44: I52 (1969).

21. Levin, B., Dobbs, R. H., Burgess, E. A., and Palmer, T.: Hyperammonaemia: A variant type of deficiency of liver ornithine transcarbamylase. Arch. Dis. Childhood, 44: 162 (1969).

22. Marshall, M., and Cohen, P. P.: Ornithine transcarbamylase from Streptococcus faecalis and bovine liver. I. Isolation and subunit structure. J. Biol. Chem., 247: 1641 (1972).

23. Marshall, M., and Cohen, P. P.: Ornithine transcarbamylase from Streptococcus faecalis and bovine liver. I1. Multiple binding sites for carbamyl-P and L-norvaline, correlation with steady state kinetics. J. Biol. Chem., 247: 1654 (1972).

24. Matsuda, 1., Arashima, S., Nambu, H., Takekoshi, Y., and Anakura, M.: Hyperammonemia due to a mutant enzyme of ornithine transcarbamylase. Pediatrics. 48: 595 (1971).

25. Nagayama, E., Kitayama, T., Oguchi, H., Ogata, K., Tamura, E., and Onisawa, J.: Hyperammonemia: A deficiency of liver ornithine transcarbamylase. Pediat. Univ. Tokyo, 18: 167 (1970).

26. Palmer, T., Oberholzer, V. G., Burgess, E. A., Butler, L. J., and Levin, B.: Hyperammonaemia in 20 families: Biochemical and genetical survey, including investigations in 3 new families. Arch. Dis. Childhood, 49: 443 (1974).

27. Reichard, H.: Ornithine carbamyl transferase activity in human tissue homogenates. J. Lab. Clin. Med., 56: 218 (1960). 
28. Reichard, H.: Serum ornithine transcarbamylase activity in normal individuals. Enzymol. Biol. Clin., 1: 47 (1961)

29. Short, E. M., Conn, O. H., Snodgrass, P. J., Campbell, A. G. M.. and Rosenberg, L. E.: Evidence for X-linked dominant inheritance of ornithine transcarbamylase deficiency. N. Engl. J. Med., 288: 7 (1973).

30. Snodgrass, $\mathbf{P}$. J.: The effects of $\mathrm{pH}$ on the kinetics of human liver ornithine-carbamyl phosphate transferase. Biochemistry, 7: 3047 (1968).

31. Snodgrass, P. J., and Parry, D. J.: The kinetics of serum ornithine carbamoyltransferase. J. Lab. Clin. Med., 73: 940 (1969).

32. Thaler, M. M., Hoogenraad, N. J., and Boswell, M.: Reye's syndrome due to a novel protein-tolerant variant of ornithine-transcarbamylase deficiency. Lancet ii: 438 (1974).

33. Wolfson, S. K., and Williams-Ashman, H. G.: Isocitric and 6-phosphogluconic dehydrogenase in human blood serum. Proc. Soc. Exp. Biol. Med., 96: 231 (1957).

34. Wroblewski, F., and LaDue, J. S.: Serum glutamic-pyruvic transaminase in cardiac and hepatic disease. Proc. Soc. Exp. Biol. Med., 91: 569 (1956).

35. Informed consent was obtained for this investigation and, where appropriate, for other procedures detailed in this paper.

36. Radiochemical Centre, Amersham, England.

37. This research was supported in part by the Institute for Research into Mental and Multiple Handicap.

38. Requests for reprints should be addressed to: R. J. Pollitt, Ph.D., M.R.C. Unit for Metabolic Studies in Psychiatry, Middlewood Hospital, P.O. Box 134, Sheffield, S6 ITP, England (UK).

39. Accepted for publication May 21, 1976
Linear growth retardation, growth zinc deficiency

\title{
Growth Retardation and Zinc Nutrition
}

\author{
NOEL W. SOLOMONS ${ }^{(20)}$ AND ROBERT L. ROSENFIELD \\ Departments of Medicine and Pediatrics, Pritzker School of Medicine, University of Chicago, Chicago, Illinois, USA
}

ROBERT A. JACOB AND HAROLD H. SANDSTEAD

United States Department of Agriculture, Agricultural Research Service, Human Nutrition Laboratory. Grand Forks. North Dakota, USA

\section{Extract}

Based on a previous report of a zinc deficiency syndrome in children characterized by low hair zinc, anorexia, poor growth, and hypogeusia, 12 children attending a pediatric endocrinology clinic for growth retardation and judged as having short stature as a variant of normal (SVN) were evaluated as to their zinc nutriture to learn whether zinc deficiency was a contributory factor. None was found to have the above syndrome, although one child did have a hair zinc concentration below $70 \mu \mathrm{g} / \mathrm{g}$. The mean hair zinc of the SVN subjects was lower than the hair zinc of $\mathbf{4 0}$ apparently normal adolescents, $131 \pm 37 \mu \mathrm{g} / \mathrm{g}$ vs. $168 \pm 44 \mu \mathrm{g} / \mathrm{g}(\mathrm{P}<0.02)$, but there was no difference found in plasma levels of zinc or in taste acuity. In contrast, five patients with total growth arrest secondary to juvenile Crohn's disease ( $C D$ ) were found to have multiple findings consistent with zinc deficiency including low plasma zinc, low hair zinc, or hypogeusia.

\section{Speculation}

There is a relationship between the pattern of growth and zinc deficiency in man. The pattern is characterized by a plateau in growth. The short stature of children whose growth is at a normal velocity is not likely to be due to zinc deficiency.

The trace metal, zinc, has an essential role in protein and nucleic acid metabolism in growth and development $(10)$ and in taste acuity $(5,13)$. In man, dwarfism and hypogonadism responsive to zinc have been reported from Egypt (7) and Iran (3). A major factor in the 'occurrence of the syndrome appears to be the low bioavailability of dietary zinc because of chelation by the phytate and fiber in the high extraction whole grain bread which is a major component of the diet (8). An additional factor in Iran is the practice of geophagia; in Egypt infestations with hookworm and schistosomiasis contribute. Zinc deficiency has been implicated in the growth retardation and delayed sexual maturation seen in cystic fibrosis (4), sickle cell disease (1), and Crohn's disease (14). Hambidge et al. (5) measured the concentrations of zinc in the hair of 132 adolescents and children between the ages of 4 and 17 years; of 10 children with hair levels below $70 \mu \mathrm{g} / \mathrm{g}$ (ppm), 9 had heights below the 10th percentile and 7 had a history of poor appetite. Objective evidence of impaired taste acuity was found in 5 of 6 of the children tested. After treatment, these children showed improved taste and improved appetites, and their growth failure was therefore attributed to zinc deficiency. Although growth retardation accounts for about a third of the patients referred to pediatric endocrinologists, in a majority of such patients no nutritional or pathologic causes can be found (17). The present study was conducted to learn whether there is a substantial incidence of zinc deficiency among children evaluated for short stature in pediatric clinics, and to assess the relationship of zinc nutrition to linear growth.

\section{PATIENTS, MATERIALS, AND METHODS}

Patients were selected from among new or recent registrants in the Pediatric Endocrinology Clinic of the Wyler Children's Hospital who presented with a chief complaint of short stature. Twelve patients with unexplained short stature were studied. All were below the 3 rd percentile for height according to the anthropometric data of the Iowa Child Welfare Research Station and the Harvard School of Public Health. They ranged in age from 5 to 17 